\title{
DAXX wt Allele
}

National Cancer Institute

\section{Source}

National Cancer Institute. DAXX wt Allele. NCI Thesaurus. Code C52221.

Human DAXX wild-type allele is located in the vicinity of $6 \mathrm{p} 21.3$ and is approximately $4 \mathrm{~kb}$ in length. This allele, which encodes death domain-associated protein 6 , is involved in transcriptional attenuation. 